\title{
津波に対する島のレンズ効果
}

\section{その 1.1993 年北海道南西沖地震津波}

\author{
日本歯科大学新潟短期大学* 阿 部 邦 昭
}

\section{Focusing Effect of Islands on a Tsunami}

\section{Part 1. A Case of the 1993 Hokkaido Nansei-oki \\ Earthquake Tsunami}

\author{
Kuniaki ABE \\ Niigata Junior College, Nippon Dental University, \\ Hamaura-cho 1-8, Niigata, 951 Japan \\ (Received December 8, 1994; Accepted January, 29, 1996)
}

\begin{abstract}
Local amplifications of tsunami were found on the maximum inundation heights at Japanese 10 coasts facing islands in the 1993 Hokkaido nansei-oki earthquake tsunami. For each island-coast geography a peak height $(H)$ at a coastal focus, a background average height $\left(H_{0}\right)$, a peak width $(W d)$, a coastal focus distance from the island $(L)$ and an island size $\left(L_{0}\right)$ are defined on the space distribution of maximum heights obtained in the surveys and the relations are discussed.

Main results are as follows: Amplification ratio $H / H_{0}$, plotted as a function of coastal focus distance from an island, are distributed in the vicinity of 2 . The peak width relative to the island size $W d / L_{0}$ is proportional to the focus distance relative to the island size $L / L_{0}$. There is a negative correlation relation between the amplification ratio and the relative peak width. These facts suggest that the amplification was caused by a superposition of incident waves on the sea in the rear of the island slope after being separated into two and refracted on the slope. Thus, the amplification at the coast facing islands is explained from a focusing effect of islands on a tsunami.
\end{abstract}

Key words: Hokkaido nansei-oki earthquake tsunami, Focusing effect of islands.

§1. はじめに

津波エネルギーが島に向かって収束することは，島が 深海加ら筒状に突き出ているのではなく，周囲に裾野 をもって立ち上がっている事と津波の速度が水深の平方 根に比例していることに由来する. НомmA (1950) は回 転放物面状の水深分布を持つ島に正弦波が入射した場合 の島の周囲での増幅度の解析解を求めている. 1960 年 のチリ津波では八ワイ諸島で水位の増加が見られたため に，モデル実験や数值実験が盛んに行われた［例えば， Williams and Kartha (1967), Vastano and Reid (1967) など]. 一方，同じ津波がポリネシアやハワイ諸 島を通過することによって，日本のような後背地に高水 位をもたらす可能性に注目した今村・他 (1990) は，こ

* ₹951 新潟市浜浦町 1-8
の津波が太平洋を横切って伝わる数值実験を行い，島の 周囲の浅瀬が原因で津波が収束している事を確認した。 これは島によって $2 つ に$ 別れた波がそれぞれ周囲の浅 瀬によって島の中心方向に屈折して同じ位相で重ね合わ さるためと考えられる.ちょうどこれは凸レンズによっ て光波が屈折し収束する状態に似ているので, レンズ効 果之呼ばれている. 1983 年日本海中部地震津波の際に, 都司・他 (1984) は朝鮮半島の東海岸で津波が異常に高 かったことに注目し，その原因を説明できる4つの可能 性の 1 つとして稀陵島によるレンズ効果をあげている が具体的な検討はしていない.

1993 年 7 月 12 日の北海道南西沖地震 $(M=7.8)$ によ る津波は，1983 年日本海中部地震津波を淩ぐ高さに発 達し, 奥尻島や北海道本島南西部で多数の犠牲者と家屋 の流失を出している．この時新潟県の栗島の対岸にあた 
る桑川では $2.89 \mathrm{~m}$ を記録し, 島から遠い海岸での高さ $1.7 \mathrm{~m}$ に対して 1.7 倍に増幅されていて, 島によるレン ズ効果があった事が指摘された [阿部・他(1994)]. 同 時にこのような効果が他の島の対岸についても見られる ことが阿部 (1994) によって指摘された.ここではさら に島の数を増やし, 定義をより明確にしてレンズ効果に ついて定量的な解析を試みる.

\section{§2. 島の対岸での津波水位の増加}

1993 年北海道南西沖地震津波の最大水位は痕跡や聞
き取り調査によって調べられ，北海道北部から島根県に いたる日本海沿岸について個別にまとめられている．北 海道北部は後藤・他 (1994), 奥尻島, 北海道南西部, 本 州東北地方海岸は首藤 (1994), 新潟県は阿部・他 (1994), 富山県から島根県に及ぶ本州西部は都司・他 (1994) によるものがある.これらのデータと奥尻島, 北 海道南西部における筆者の調査結果を使って, 沖に島が あるような海岸での津波水位分布を調べた．津波水位は すべて東京湾平均海面からの高さ $(\mathrm{m})$ に換算して扱う. 津波発生時の新潟港での潮位は上記東京湾平均海面上

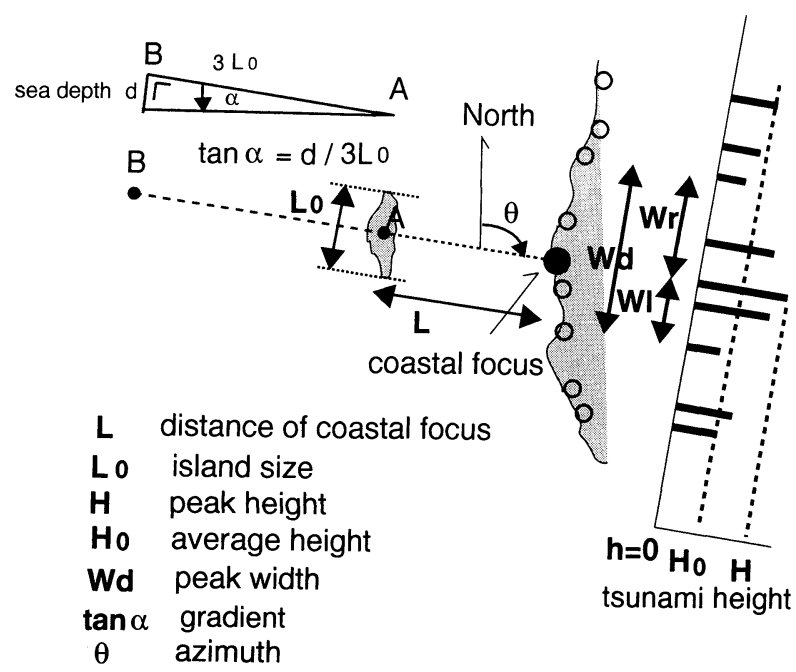

Fig. 1. Definition of related parameters. Coastal focus (solid circle), peak height at this point $(H)$, average height at the coast distant from the focus $\left(H_{0}\right)$, right width $(W r)$ of high-leveled region, left width $(W l)$ and total peak width $(W d)$ as the sum, distance from a center of island to the coastal focus $(L)$ which is abbreviated as a coastal distance, island size $\left(L_{0}\right)$ and azimuth of focal vector $(\theta)$. Gradient of sea bottom $(\tan \alpha)$ is defined to a horizontal distance equal to $3 L_{0}$.

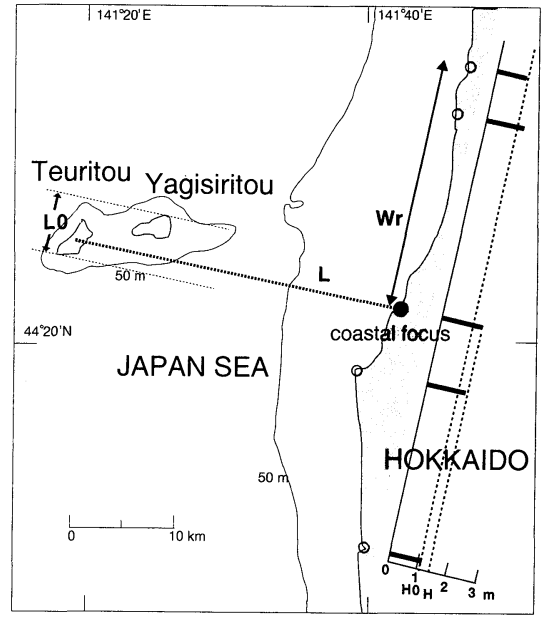

Fig. 2(a). Observed tsunami heights and parameters for Teuritou.

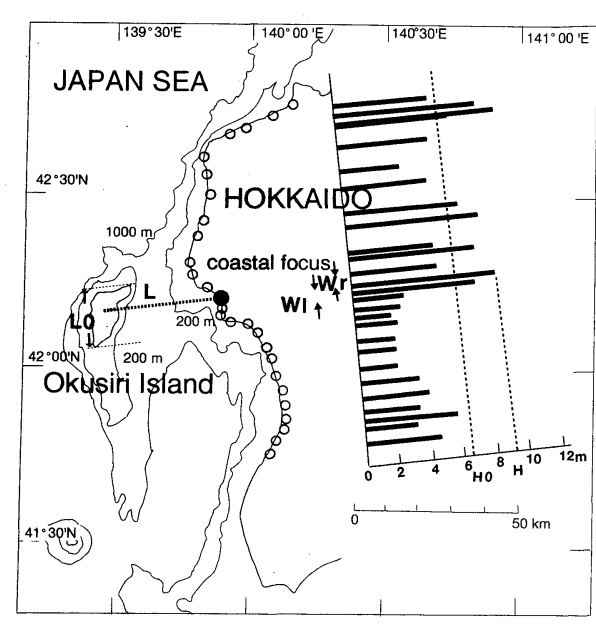

Fig. 2(b). Observed tsunami heights and parameters for Okusiri Island. 


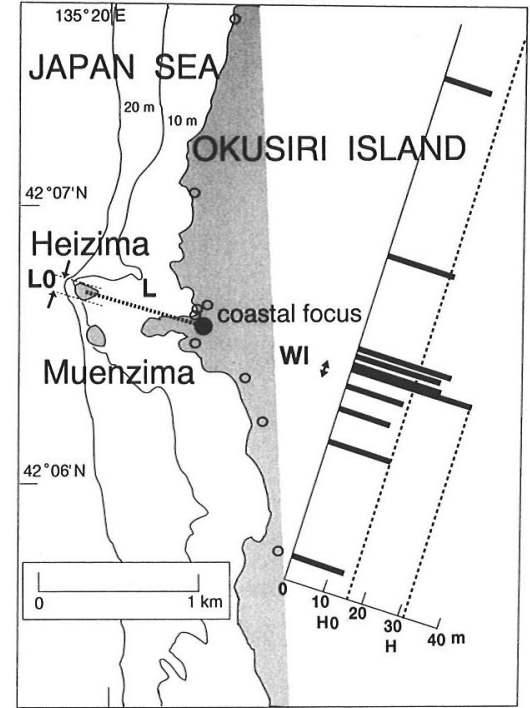

Fig. 2(c). Observed tsunami heights and parameters for Heizima.

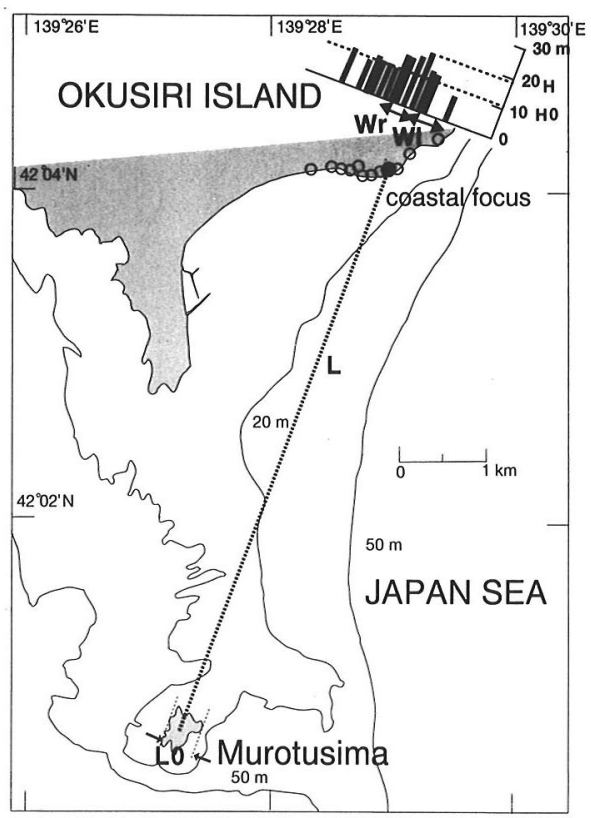

Fig. 2(d). Observed tsunami heights and parameters for Murotusima.

$0.3 \mathrm{~m}$ であるので，実質の波は津波最大水位より $0.3 \mathrm{~m}$ 程度低い之考えられるが, 最大水位の到達時刻がわから ないので実質の高さを正確に知ることができない［阿 部・他 (1994)]. そのため実質の波の高さに代わって最 大水位で議論する.

水位分布の特徴を表現するための定数を定義しておく (Fig. 1). 島の対岸で極大值の現れているところを海岸焦

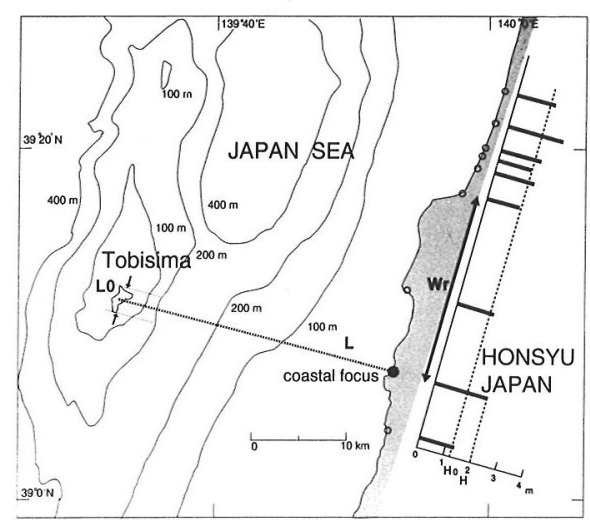

Fig. 2(e). Observed tsunami heights and parameters for Tobisima.

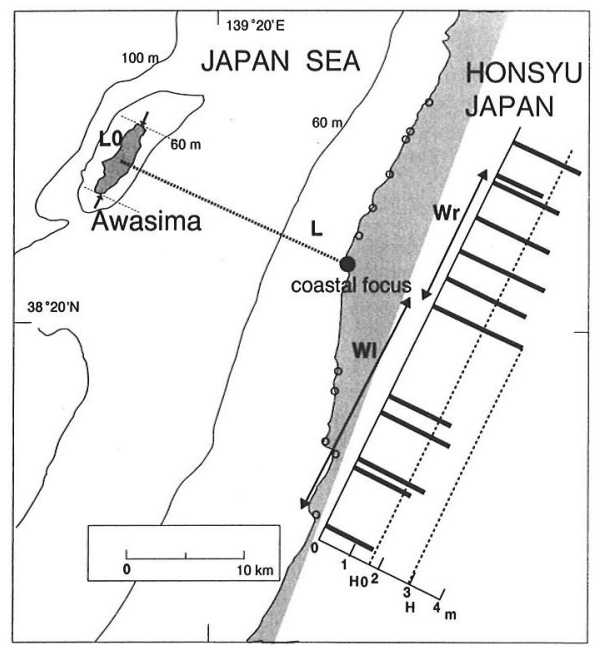

Fig. 2(f). Observed tsunami heights and parameters for Awasima.

点 (coastal focus) と呼ぶことにし,この海岸焦点と島の 中心を結ぶ線分の長さを海岸焦点距離 (distance of coastal focus) とし $L$ で表わす．これはいわゆる焦点距 離ではなく, 海岸で発現した極大值点までの距離という 意味である。この線分を島から海岸にむく焦点ベクトル と呼ぶことにし，その方位を北から時計回りの方向に 測った海岸焦点の方位角と呼び， $\theta$ で表わす．またこの 


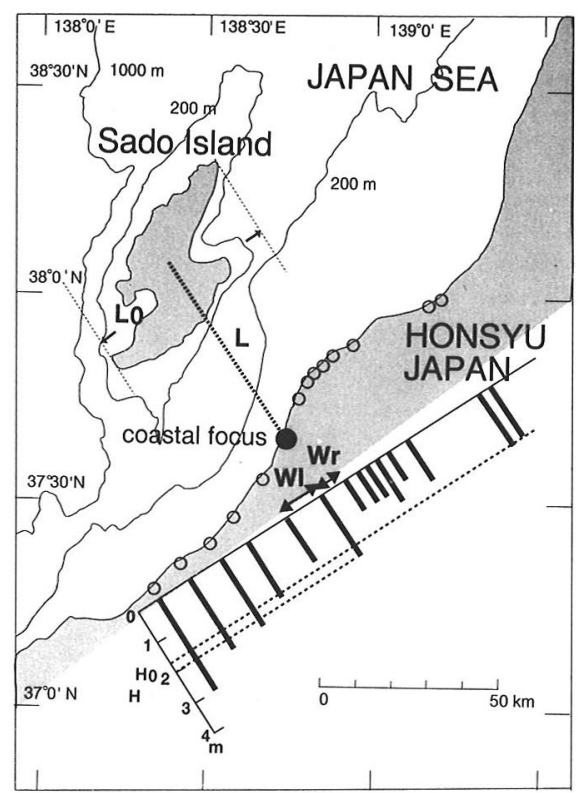

Fig. 2(g). Observed tsunami heights and parameters for Sado Island.

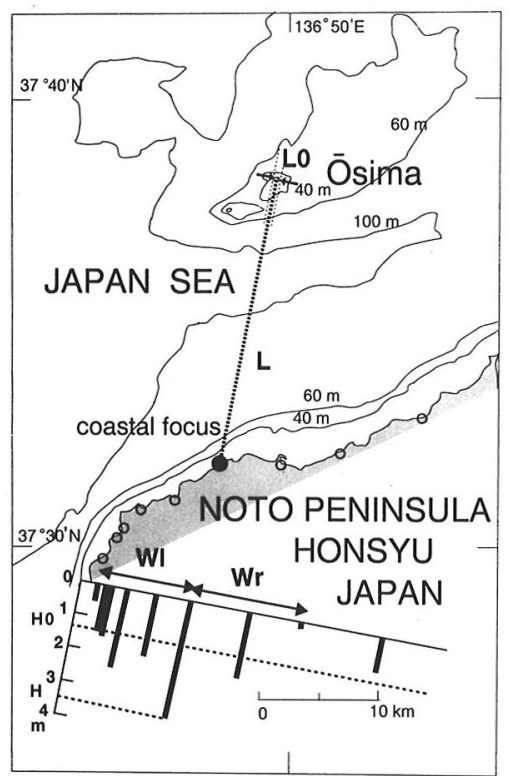

Fig. 2(h). Observed tsunami heights and parameters for Osima.

線分に直交する方向に島の断面を投影したときの断面の 長さを島の大きさ (island size) とし， $L_{0}$ とする.これで 島のサイズを代表させる。これは海岸焦点からみた島の 断面の長さである。あし島が 2 つ上上近接してある場合 は，断面が重なる場合に限り 1 つの島とみなして，断面

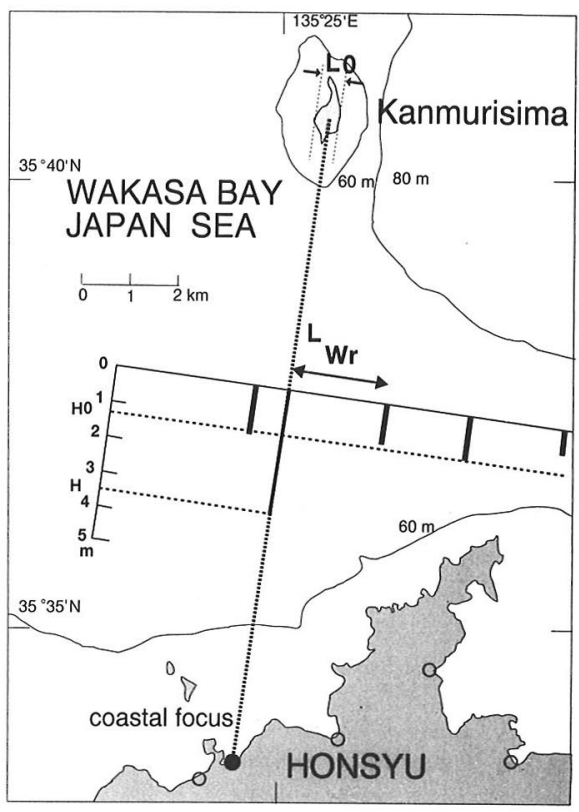

Fig. 2(i). Observed tsunami heights and parameters for Kanmurisima.

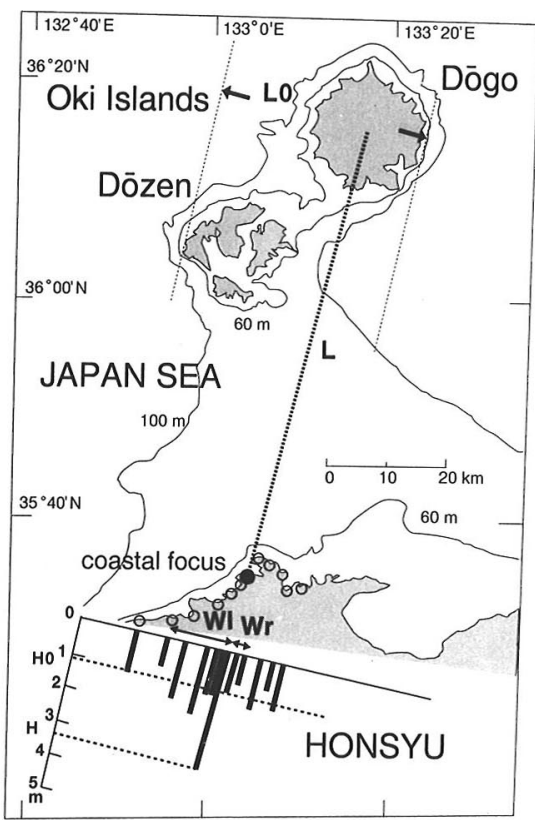

Fig. 2(j). Observed tsunami heights and parameters for Dogo (Oki Islands).

の長さで定義することにする．また島の中心から測った 震央距離を $\Delta$ で表わす。水位分布は焦点べクトルに直 交する面に射影したもので考え, 海岸焦点の水位である 極大值を $H$, 島から遠く離れて島の影響がないとおもわ れる 2,3 地点の水位加らとめた平均值を $H_{0}$ とする. 
Table 1. Parameter list. Epicentral distance $(\Delta)$ is defined to a center of island. Underlined value for $W r$ or $W l$ is repetition of the opposite side because of data lacking or the case of twin islands. The definitions are shown in Fig. 1.

\begin{tabular}{|c|c|c|c|c|c|c|c|c|c|c|}
\hline islands & 島 & $\Delta(\mathrm{km})$ & $\mathrm{L}(\mathrm{km})$ & $\mathrm{L}_{0}(\mathrm{~km})$ & $\theta(\operatorname{deg})$ & $\mathrm{H}(\mathrm{m})$ & $\mathrm{H}_{0}(\mathrm{~m})$ & $\mathrm{Wr}(\mathrm{km})$ & $\mathrm{H} 1(\mathrm{~km})$ & $\mathrm{Wd}(\mathrm{km})$ \\
\hline Teuritou & 天売島 & 280 & 30 & 5.6 & 102 & 1.4 & 1. 1 & 24.0 & 24.0 & 48.0 \\
\hline Okusiri & 奥尻島 & 110 & 35 & 19 & 84 & 9.0 & 6.2 & 6.0 & 7.0 & 13.0 \\
\hline Heizima & 平島 & 100 & 0.75 & 0.1 & 105 & 31.7 & 16.6 & 0.1 & 0.1 & 0.2 \\
\hline Murotusima & 室津島 & 130 & 6.8 & 0.36 & 22 & 19.2 & 10.7 & 0.4 & 0.3 & 0.7 \\
\hline Tobisima & 飛島 & 450 & 29 & 3 & 105 & 2.0 & 1.3 & 20.0 & 20.0 & 40.0 \\
\hline Awasima & 粟島 & 530 & 20 & 7 & 115 & 2.9 & 1.7 & 12.0 & 19.2 & 31.2 \\
\hline Sado & 佐渡島 & 580 & 57 & 55 & 148 & 2.0 & 1.7 & 7.0 & 13.0 & 20.0 \\
\hline Osima & 大島 & 660 & 24 & 0.4 & 190 & 3.5 & 1.3 & 9.4 & 7.4 & 16.8 \\
\hline Kanmurisima & 冠島 & 910 & 13 & 0.6 & 188 & 3.5 & 1.3 & 2.1 & 2.1 & 4.2 \\
\hline $0 \mathrm{ki}-\operatorname{dog} \mathrm{O}$ & 隠岐島後 & 970 & 76 & 34 & 193 & 3.4 & 1. 1 & 3.2 & 9.6 & 12.8 \\
\hline
\end{tabular}

その水位分布が極大值から小さくなって, 一度平均值を 下回った後，再び平均值に回復することに注目し，平均 值を下回った点で最も海岸焦点に近い点を島に向かって 右と左でそれぞれ選び，海岸焦点からそこまでの断面図 上の直線距離をそれぞれ $W r, W l$ とする. そしてその和 を高水位域の幅すなわちピーク幅 $W d$ と定義する. 適当 な位置にデー夕が無くて片方しか定義できない場合は片 方の距離の 2 倍を使って幅 $W d$ とする.

先の水位調査デー夕をもとに日本海で島のある所の対 岸の津波水位分布を調べたところ, 島の無い所に比較し て多かれ少なかれ水位の増加が 10 個所で認められた。

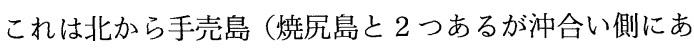
る手売島で代表させる), 平島 (奥尻島藻内沖), 室津島 (奥尻島青苗沖), 奥尻島, 飛島, 粟島, 佐渡ガ島, 大島 (能登半島輪島沖), 冠島 (若狭湾), 島後 (隱岐ノ島) の 対岸部である。な扭波波源に近い渡島大島，小島の対 岸には津軽海峡があって島の津波に及ぼす影響を確認で きない．水位の増加が見られた島の対岸での水位分布を 再現したのが Fig. 2(a)-(j) である. 各図には海岸焦点の 位置, そこの水位および周辺の水位，ピーク幅などが示 してある. 得られたパラメ一タ $\Delta, L, L_{0}, \theta, H, H_{0}, W r$, $W l, W d$ の值を表で示したのが Table 1 である. 島のサ イズ $L_{0}$ は小さいもので $0.1 \mathrm{~km}$ から大きいものは 22 $\mathrm{km}$ に执よび, 海岸焦点距離 $L$ は $0.7 \mathrm{~km}$ から $78 \mathrm{~km}$ に わたっている.これらのデータの中には少ないデータを 使って得られたもの (手売島, 冠島) や偏っているデー 夕によっているあの (飛島, 冠島) などが交じっており, 個々の值には相当任意性がある事を認めなければならな い. そうした状況のなかでできる限り一貫性を保てるよ うに決めたのがこれらのパラメータである.

得られた結果から焦点べクトルの向きを図示すると Fig. 3 が得られる.これをみると震源近くでは波源域境

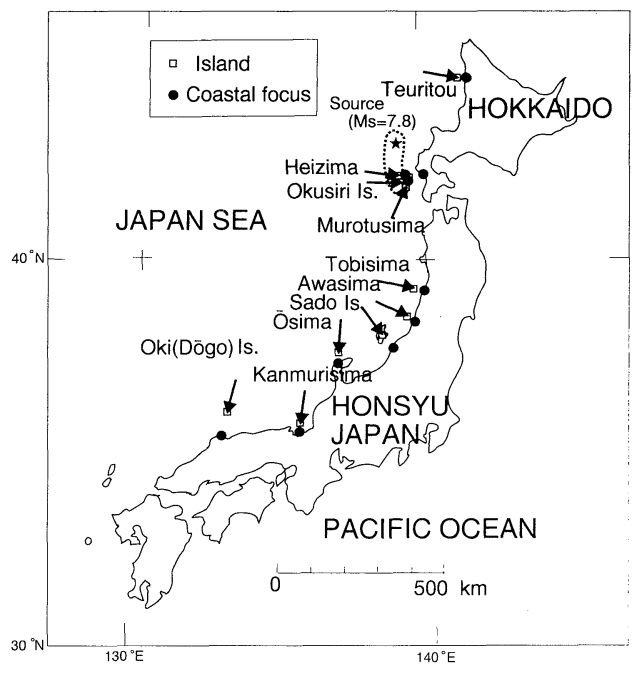

Fig. 3. Coastal focuses and azimuthes of the focal vectors observed in the 1993 Hokkaido Nansei-oki Earthquake Tsunami. Epicenter (solid star) and assumed tsunami source area (dotted line) which was modified from that by Hatori (1994).

界線と直交する方向に近く, 中程度の距離にある手売島 や本州各島では海岸線に直交する方向に近くなっている のが特徴である. 手売島, 飛島, 粟島などは波源域に対 する方位とこのベクトルの方位の間に大きなずれが見ら れるが, 後で述べるようにこの高水位は島の周囲で屈折 した波の重なりあったものだとすると高水位に寄与した 津波はこのベクトルの方向に入射したものと考えられ る.この津波の伝搬図が羽鳥 (1994)や岡田・中村 (1994)によってだされているが，それによるとこれらの 島の周辺では海岸により斜めに入射しているように見え る.この違いは伝搬図に示されるものは津波の第 1 波の 波面であり, 高水位に寄与したのは遅れて沖の方から 


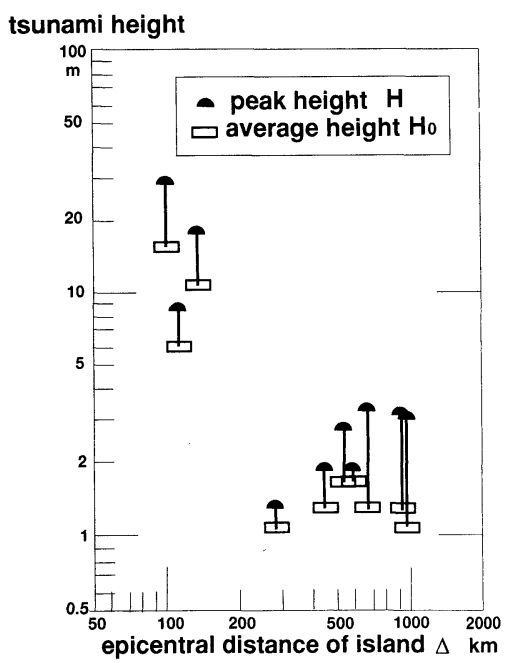

Fig. 4. Tsunami average heights (open rectangls) above mean sea level at Tokyo bay and the increase at the coastal focuses (solid half circles) for epicentral distances of islands opposite to the focuses.

やってきた波であるとすればよい，反射や回折があると このような事が起こりえる. 観測された水位の平均值 $H_{0}$ と極大值 $H$ を関連する島の震央距離 $\Delta$ に対してプ ロットした図が Fig. 4 である.これをみると震央距離と とあに減衰している平均值 $H_{0}$ のレベルから 2 倍程度ま で極大值 $H$ が増加しているのがわかる．震央距離によ る変化を良く見ると 280 から $500 \mathrm{~km}$ のあたりで増幅 度が比較的小さい。このあたりが先に指摘した焦点べク トルの方向が第 1 波の伝搬方向と異なる点に対応して いる.

レンズ効果の尺度として極大值を周囲の平均值で割っ た值 $H / H_{0}$ すなわち増幅度を取ったとき，10例につい て増幅度は 1.0-1.5 が 3 例, 1.5-2.0 が 4 例, 2.0-3.0 が 2 例，3.0-4.0 が 1 例となり，1.5-2.0 の場合が最も多い 分布になっている. この点で興味深いのは奥尻島藻内で 観測された $31.7 \mathrm{~m}$ という高い值である. ここは平島の 対岸になっていて V 字形の谷をかけあがったとされて いるが，この值は平均值 $16.6 \mathrm{~m}$ のほぼ 2 倍になってお り特別他の島の場合と増幅度が変わらないことが注目さ れる。 また佐渡や奥尻などの比較的大きな島の対岸でも 平均值より高い水位（増幅度にして 1.18, 1.45）が観測 されていることである.この点は奥层, 佐渡では増幅度 が 1 より小さいとした結果 [阿部(1994)] と違うが，こ れは両島において海岸焦点での水位の高い点が見落とさ れていたためである.

\section{§3. レンズ効果による水位分布の特徵}

まず島のサイズと海岸焦点距離の関係をみたのが Fig. 5 である. 海岸焦点距離が任意に取れる值ではなく 対岸までの最短距離に近い固定的なものと考えると, 対 象としている島がサイズに関して 3 種類に分類でき, こ れらの対岸距離もサイズに応じてグループ分けができ る.つまりサイズの $1 \mathrm{~km}$ 未満が 4 島, $1 \mathrm{~km}$ 以上 10 $\mathrm{km}$ 未満が 3 島, $10 \mathrm{~km}$ 以上 $100 \mathrm{~km}$ 未満が 3 島であ る.この内対岸距離が相対的に幅広く分布するのは最す 小さいサイズの島だけであり，ほかは分布が $10 \mathrm{~km}$ の オーダーに限られる，得られたデータはこのような制約 下にある. 結果的には同じサイズのものは類似の結果を

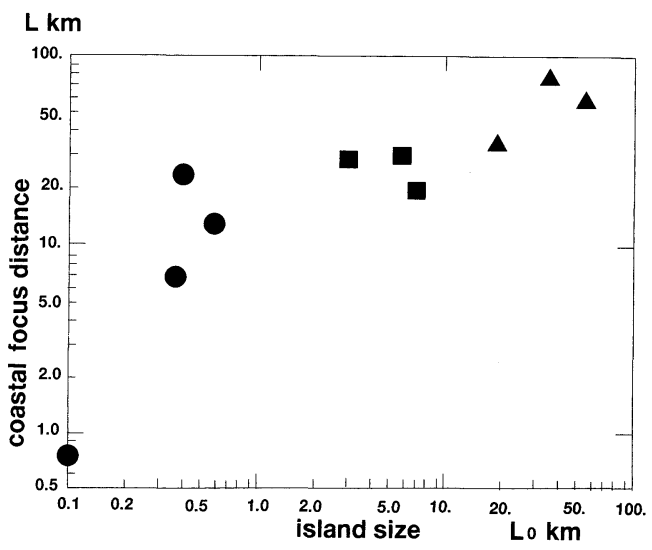

Fig. 5. Relation between coastal focus distance $L$ and island size $L_{0}$. Islands are classified according to island sizes into three groups, which are large sized (solid triangle, $L_{0} \geq 10$ $\mathrm{km}$ ), middle sized (solid squares, $1 \leq L_{0}<10$ $\mathrm{km}$ ) and small sized (solid circles, $L_{0}<1$ $\mathrm{km})$.

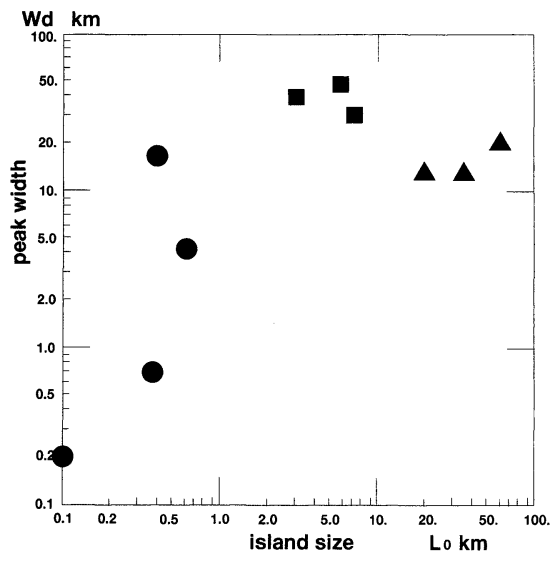

Fig. 6. Variations of peak width $W d$ versus island size $L_{0}$. The same classification as in Fig. 5. 
示すので以下この分類を使うことにし，小サイズの島の 場合は黒丸，中サイズは黒四角，大サイズは黒三角でプ ロットする.

高水位域の幅 $W d$ を縦軸に, 島のサイズ $L_{0}$ を横軸に

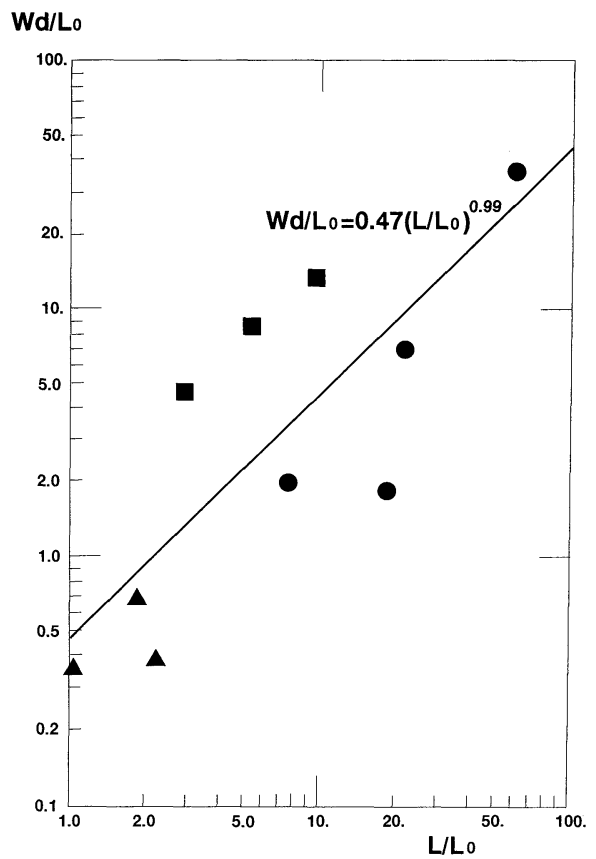

Fig. 7. Variation of peak width relative to island size, $W d / L_{0}$, versus relative coastal distance, $L / L_{0}$.

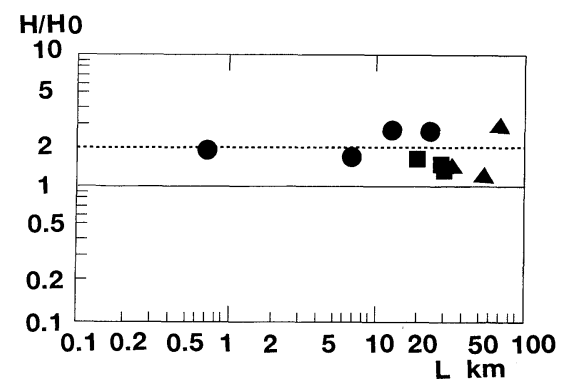

Fig. 8. Dependence of amplification ratio $H / H_{0}$ on coastal focus ditance $L$.
取ってプロットしたのが Fig. 6 である.これは大サイズ の 3.島がやや小さくなったことを除けば Fig. 5 と似た 分布を示す。この事から高水位域の幅 $W d$ は海岸焦点距 離 $L$ と比例することが予想できる．それを見たのが Fig. 7 である. 大サイズの 3 島を除けば良い比例関係を示し ている.島のサイズが 100 倍の範囲で変わるのに高水位 域の幅 $W d$ を絶対值で扱うのは一般的ではないので島 のサイズ $L_{0}$ で規格化してプロットしてある．直線性が かなりよいので最少自乗法を適用すると式

$W d / L_{0}=0.47\left(L / L_{0}\right)^{0.99}$

が得られる. 次数は 0.99 となることから相対幅は相対 距離の 1 次式で近似され, 両者は比例していることが確 かめられる．これを詳細にみると中サイズの 3 島は勾配 は同じながらあ小サイズの島の幅より大きな幅をもって 推移し，大サイズの島の幅は小サイズの島の幅と同じ傾 向を示す事がわかる. 平均より上にでている 3 つの中サ イズの島の場合震央距離が中規模であって波源を海岸に 対して斜め方向にみる点にあるという意味で共通の位置 関係にある.このことと平均より大きく推移することの 間には何等かの関係があるかあしれない。

次に増幅度 $H / H_{0}$ の海岸焦点距離 $L$ との関係をみた のが Fig. 8 である.この図では増幅度 2 に対して点線を 引いてあるが海岸焦点距離が小さいもの程 2 に近づく ようにみえる。これは文字どおり解釈すると 2 倍からず れるにはそれなりの海岸焦点距離を必要とすることを意 味する．次に増幅度と島のサイズに相対的なピーク幅の 関係を見たのが Fig. 9 である.これをみると増幅度と ピーク幅は無関係かややピーク幅とともに増加する傾向 をしめしていることがわかる．ピーク幅と海岸焦点距離 は比例するのだから, 増幅度と海岸焦点距離の関係もこ れと類似した関係になる。

増幅度に影響をあたえるものとして，島の周囲の海底 勾配が考えられる。そこでその海底勾配を焦点べクトル の逆方向にたどり (Fig. 1 参照), 島のサイズの 3 倍の水 平距離での水深を取ってその比をその島の海底勾配とす る. 水深を見込む角度を $\alpha$ とするとき $\tan \alpha$ であるこの 海底勾配に対して増幅度を取ったのが Fig. 10 である.

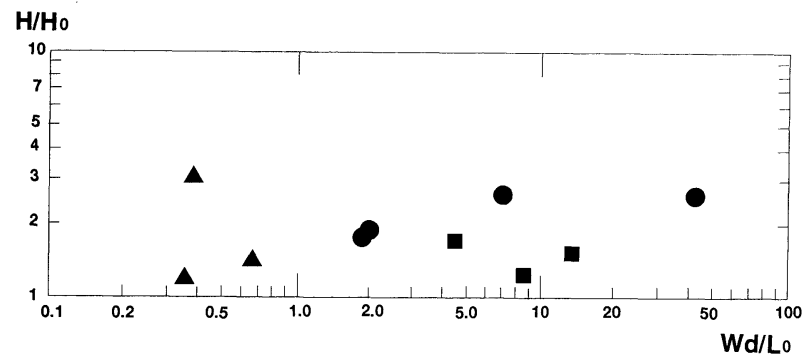

Fig. 9. Dependence of amplification ratio $H / H_{0}$ on relative peak width $W / L_{0}$. 


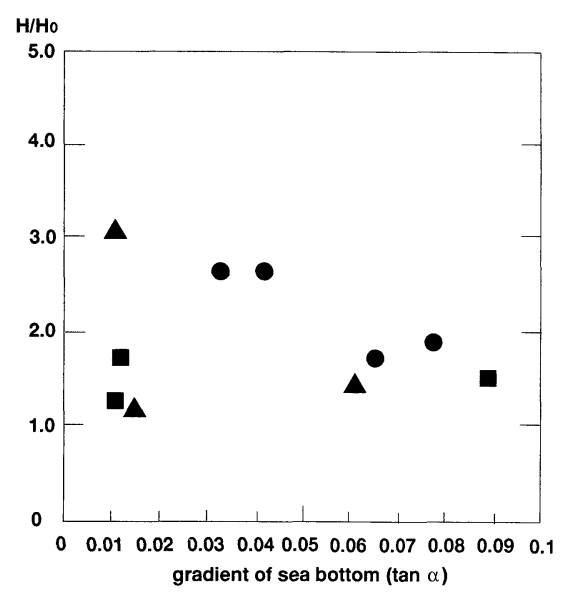

Fig. 10. Correlation between amplification ratio $H / H_{0}$ and gradient of sea bottom in front of island $\tan \alpha$ (see Fig. 1).

これをみると大きくはないが負の相関関係が認められ る.このことは, 外海側の勾配が小さい場合により対岸 に津波が収束しやすいことを示している．増幅度が 2 よ り大きくなる理由は小さい海底勾配にあるといえる。し かし海底勾配が小さいにもかかわらず，増幅度の小さ かった場合あある。これは現れている島の波源にたいす る位置関係からみて波線が島の近くで曲げられて，左右 の波のコヒーレントな性質が失われたとか，平均水位に 寄与した波と極大值に寄与した波が違うなどの原因が考 えられる. 最後に増幅度を縦軸に海岸焦点距離に相対的 なピーク幅を横軸にとってみると，両者には負の相関が 認められることを示すことができる (Fig. 11). 前にピー ク幅と海岸焦点距離は比例する事を述べている。した がって横軸の持つ意味は比例関係からのずれの大きさと みなせる．比例関係からのずれの大きいものほど増幅度 が小さい事になる.

\section{§4. 考察}

これらの結果は大部分の島ではその対岸で増幅度が 2 前後に増幅され，さらに島の周囲の海底勾配が小さい場 合はそれよりさらに大きく増幅されることを示してい る. 阿部 (1995) は円錐状の裾野を持った直径 $3 \mathrm{~km}$ の 円筒状の島に津波を摸した線形長波長平面波が入射する 場合を数值実験で調べ，島の後ろ側での最高水位の分布 を調べた。 それによると島のすぐ後ろで何れも最も高く なり，入射波の周期が $20,10,5$ 分の場合に増幅度はそ れぞれ 1.1, 1.3, 1.8 になり，周期が短い場合に 2 に近く なる事を示した。この実験では海岸の傾斜部分の影響は 考慮されていないが，その事を観测された増幅度が 2 に 近いことと比較すると，数值実験の短周期の波に対して 得られたような状況が実現されたと考えることができ る。ただし重ねあわせで 2 倍になるのは線形の場合で あって，非線形の場合は推測が難しい，なお数值実験の 結果では增幅度は島からの距離とと屯に減少する．観測 では一つの島に対する結果ではなくて，種々の島に対す る結果ではあるが Fig. 8 に見るように減少しているあ のああるし，逆に増加しているあのあある．ただしすで に指摘したように増加しているあのについては海底勾配 が小さいという共通の要因がある．増幅度が 2 より大き いものがあるということは観測結果が単純に左右の 2 つの波の重ねあわせだけでなく，両者はそれぞれが増幅 されながら重ねあわさるようなプロセスがあることを示 唆している.

また室津島の周囲の津波の振る舞いについて田中 (1994) は水理モデルによる実験を試み，対岸の高水位を 非線形ソリトンの重合として説明している．その実験で は室津島の左右の海域を通過した波が屈折してその背後 で高くなる様子が示されている，水位分布に線形と非線 形でどのような違いがでるかは明らかでないが，室津島 の左右から侵入した波が相互作用をして水位を対岸で増 加させた事は間違いない。

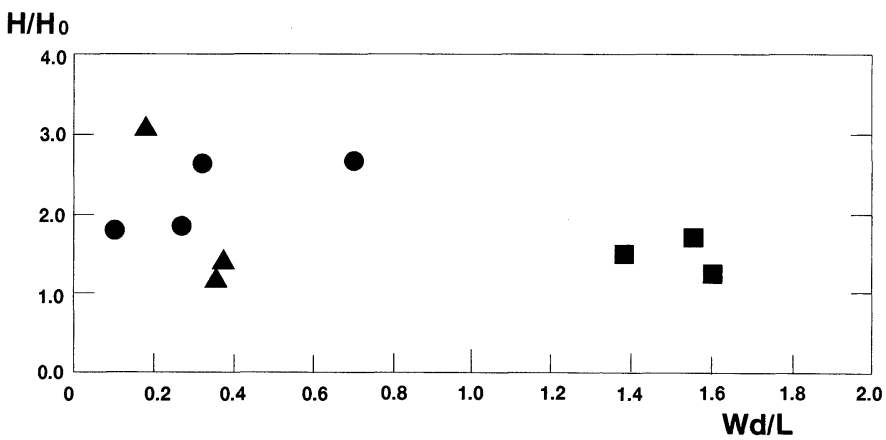

Fig. 11. Correlation between amplification ratio $H / H_{0}$ and peak width relative to coastal focus distance $W d / L$. 
ピーク幅が海岸焦点距離に比例して増加することは, 島に入射する平面波が 2 手に別れた後, 島の周囲の傾斜 した浅瀬にさしかかって平面波の性質を保ったままある 角度で焦点ベクトルに近づく方向に屈折して, 以後直進 して焦点ベクトルの上で重なり合うようなモデルを考え ると説明できる.このとき重なった部分の海岸に平行な 方向の長さは島からの距離に比例する.

なおこのモデルからはある特定の海岸焦点距離で増幅 度が極大になるいわゆる特定の焦点距離が存在するよう なイメージを描くことはできない.

\section{§ 5. 結論}

1993 年北海道南西沖地震津波で島の対岸での津波の 増幅が痕跡水位の調查結果をむとにして調べられ，10 島の対岸で確認された. 各島の場合に対して分布の断面 図を作り，極大值 $H$ が観測された点を海岸焦点として, そこを中心として観测された高水位分布の広がりの指標 となる幅 $W d$ が定義され, 極大值と平均值 $H_{0}$ の比（増 幅度）や幅の海岸焦点距離 $L$ （極大值点と島の中心間距 離）および島のサイズ $L_{0}$ との関係などが調べられた. そ の結果,

（1）島の対岸に共通に津波水位の極大值点が現れ，そ の極大值 $H$ は島から遠く島の影響がない海岸での平均 值 $H_{0}$ の 1.2 から 3.1 倍に達した. 平均増幅度は 1.9 で 2 に近い.

(2) 増幅度の海岸焦点距離による変化をみると距離 が小さいほよ゙ 2 に近づく傾向にある.

（3）増幅度が 2 より大きい島は, 周囲の海底勾配が小 さい傾向にある.

(4) 島のサイズに相対的なピーク幅は島のサイズに 相対的な海岸焦点距離に比例する.

(5) 増幅度と海岸焦点距離に相対的なピーク幅は負 の相関関係にある.

島の形や海底地形が複雑であるにあかかわらず，島の 対岸での水位の増加には以上に述べたような規則性が認 められた．極大值が平均值の約 2 倍であること, ピーク 幅が島からの距離に比例して増加することなどから, 増 幅の主な原因は島の周囲で屈折した 2 つ波の重ねあ わせ又は相互作用にあると結論づけられる。

謝辞

調查に協力してくださいました現地住民の方々, 検潮
記録を提供してくださいました各地検潮所の方々に感謝 いたします．調査にあたり，その費用の一部に文部省科 学研究費の補助金を使用しました. 査読の過程でのレ フェリーのコメントは内容の改善に役立ちました。記し て感謝いたします。

\section{文献}

阿部邦昭, 1994, 北海道南西沖地震津波に対する島のレ ンズ効果, 月刊海洋, 7, 185-191.

AвE, Ku., 1995, Numerical simulation of tsunami focusing effect by an island, Bull. Nippon Dental University, General Education, No. 24, 61-72.

$\mathrm{ABE}, \mathrm{Ku}$. and $\mathrm{H}$. IsHII, 1987, Distribution of maximum water levels due to the Japan Sea Tsunami on 26 May 1983, J. Oceanogr. Soc. Jpn., 43, 169-182.

阿部邦昭・泉宮尊司・砂子 浩・石橋邦彦, 1994, 北海 道南西沖地震津波の新潟県における浸水高の分布, 地 震研彙報, 69, 159-175.

後藤章夫・高橋浩晃・宇津木 充・小野 忍・西田泰 典 - 大島弘光 - 笠原 稔 - 竹中博士 - 斉田智治, 1994, 北海道南西沖地震に伴う津波一小樽から礼文 島まで一，月刊海洋， 7, 153-158.

今村文彦・首藤伸夫・後藤智明, 1990, 遠地津波の数值 計算に関する研究 その 2 太平洋を伝播する津波の 挙動, 地震 2, 43, 389-402.

羽鳥徳太郎，1994，1993 年北海道南西沖地震津波の規 模および波源域, 地震 2, 47, 1-9.

Homma, S., 1950, On the behavior of seismic sea waves around circular island, Geophys. Magazine, 21, 199-209.

岡田正実・中村浩二，1994，奥尻津波と検潮記録，月刊 海洋, 7, 123-131.

首藤伸夫，1994，1993 年北海道南西沖地震津波の痕跡 高, 東北大学工学部災害制御センター津波工学研究報 告, 11 ，第 2 編，調查資料，1-12.

田中茂信, 1994, 北海道南西沖地震津波の奥尻島南部浅 海域での挙動, 月刊海洋, 7, 159-165.

都司嘉宣・白 雲件・秋 教昇・安 希朱, 1984, 韓国 東海岸を襲った地震海湓, 月刊海洋科学, 9, 527-537.

都司嘉宣・加藤健二・荒井賢一・上田和枝，1994，北海 道南西沖地震津波の西日本海岸での浸水高, 月刊海 洋, 7, 192-200.

Vastano, A. C. and R. O. Reid, 1967, Tsunami response for islands: Verification of a numerical procedure, J. Marine Res., 25, 129-139.

Williams, J. A. and T. D. Kartha, 1969, Model study of long-wave amplification by circular islands, B.S.S.A, 59, 299-316. 